\title{
PENGARUH DISKUSI VERBAL DALAM REVIEW KERTAS KERJA AUDIT, PENGALAMAN KERJA, DAN MOTIVASI TERHADAP KINERJA AUDITOR PADA KANTOR BPK RI PERWAKILAN SULAWESI UTARA
}

\author{
Andrew P. Marunduh
}

(email: andrewmarunduh@gmail.com)

\begin{abstract}
Demands the implementation of public sector accountability towards the realization of good governance and claen governance in Indonesia is increasing. There are three main aspects that support the creation of good governance, namely monitoring, control and inspection. CPC was tasked to inspect / audit and give opinion on the financial statements prepared by the government.

The purpose of this research is to know about the effect of verbal discussion in the review of audit working papers, work experience, and motivation on the performance of auditors in BPK RI Representative Office of North Sulawesi.

Objects that are examined in this study is the Office of BPK RI Representative of North Sulawesi with a total population of 65 Auditor taken by census method. The independent variables used in this study is the verbal discussion (X1), work experience (X2) and motivation (X3), and the dependent variable is the performance of auditors $(Y)$. This study uses multiple regression analysis and primary data in the form of a questionnaire, while for hypothesis testing done partially.

Based on the analysis results can be seen the results of $F=12.876$ and $F$ table with a confidence level of 95\% which $d f 1$ (4-1) and $d f 2$ (65-4-1) is a significant result by 2.76 to 0.000 . So it can be seen that $F$ count $>F$ table it can be concluded that Ho is rejected and Ha accepted. Furthermore, it can be seen in the significant 0,000<0.05, it can be stated that Simultaneously, variable Verbal discussions, work experience and motivation significantly influence Auditor Performance. Results thitung for Verbal Discussion variable $(X 1)=5777$ and the significant table $=0.000$ and 2.000. From these results it can be seen that thitung $>$ ttable can be stated that Ho refused and $\mathrm{Ha}$ is received and the significant level of $0.000<0.05$ Thus Verbal Discussions Auditor significantly influence performance. Results thitung to experience variable $(X 2)=2.245$ and 0.028, and significantly table $=2.000$. From these results it can be seen that thitung $>$ ttable can be stated that $\mathrm{HO}$ rejected and $\mathrm{Ha}$ is received and a significant level of $0.028<0.05$ Thus Work Experience Auditor significant effect on performance. Results thitung for motivation variable (X3) $=2,995$ and 0,024 significant and table $=2.000$. From these results it can be seen that thitung $>$ ttable can be stated that $\mathrm{HO}$ rejected and $\mathrm{Ha}$ is received and a significant level of $0.028<0.05$ Thus a significant effect on performance motivation Auditor.
\end{abstract}

Keywords: Verbal discussions, work experience, motivation, and Auditor Performance

\subsection{Latar Belakang Masalah}

\section{PENDAHULUAN}

Tuntutan pelaksanaan akuntabilitas sektor publik terhadap terwujudnya good governance dan claen governance di Indonesia semakin meningkat. Tuntutan ini memang wajar, karena beberapa penelitian menunjukkan bahwa terjadinya krisis ekonomi di Indonesia ternyata disebabkan oleh buruknya pengelolaan (bad governance) dan buruknya birokrasi (Sunarsip, 2008). Salah satu faktor yang dapat mendukung terciptanya good governance dan clean governance adalah akuntabilitas sektor publik.

Akuntabilitas sektor publik erat hubungannya dengan praktik transparansi dan pemberian informasi kepada publik dalam rangka pemenuhan hak publik. Sedangkan good governance menurut World Bank didefinisikan sebagai suatu penyelenggaraan manajeman pembangunan yang solid dan bertanggung jawab dan sejalan dengan prinsip demokrasi dan pasar yang efisien, 
penghindaran salah alokasi dana investasi, pencegahan korupsi baik secara politis maupun administratif, menciptakan disiplin anggaran, serta menciptakan kerangka hukum dan politik bagi tumbuhnya aktivitas usaha (Mardiasmo, 2008). Menurut Mardiasmo (2008), terdapat tiga aspek utama yang mendukung terciptanya kepemerintahan yang baik (good governance), yaitu pengawasan, pengendalian, dan pemeriksaan. Pemeriksaan (audit) merupakan kegiatan yang dilakukan oleh pihak yang memiliki independensi dan memiliki kompetensi professional untuk memeriksa apakah hasil kinerja pemerintah telah sesuai dengan standar yang ditetapkan. Salah satu unit yang melakukan audit/pemeriksaan terhadap pemerintah daerah adalah Badan Pemeriksa Keuangan Perwakilan Daerah. BPK yang bertugas untuk memeriksa/mengaudit serta memberi opini terhadap laporan keuangan yang dibuat oleh pemerintah.

Dalam memeriksa laporan keuangan pemerintah, auditor melakukan tahapan audit agar audit dilakukan dengan efektif dan efisien. Tahapan audit atau proses audit diantaranya adalah pembuatan kertas kerja audit, tahapan ini sangat penting sebagai dasar auditor dalam memberikan pendapatnya atas laporan keuangan auditan. Kertas kerja merupakan bukti dilaksanakannya standar auditing dan program audit yang di telah ditetapkan (Mardiasmo 2008). Untuk meyakinkan bahwa semua prosedur-prosedur audit telah dilaksanakan kertas kerja harus diriview oleh atasan agar dapat memberikan umpan balik dan pelatihan terhadap pekerjaan yang dilakujan oleh bawahan. Selain itu dokumentasi audit dalam bentuk kertas kerja yang disiapkan oleh penyusunnya harus diriview oleh supervisor oleh karena itu merupakan bagian dari pengendalian kualitas prosedur audit laporan keuangan (Miller, 1999 dalam Wahyudi 2003). Tujuan dari review kertas kerja adalah untuk memastikan bahwa audit yang dilakukan telah mengikuti Standar Pemeriksaan Keuangan Negara (SPKN).

Selain pelaksanaan tahapan-tahapan audit yang sesuai SPKN, pengalaman seorang auditor juga menjadi factor penting dalam pelaksanaan audit. Pengalaman yang lebih akan menghasilkan pengetahuan yang lebih (Christ 2005 dalam Ilias dan Herliansyah 2009). Seseorang yang melakukan pekerjaan sesuai dengan pengetahuan yang dimiliki akan memberikan hasil yang lebih baik daripada mereka yang tidak mempunyai pengetahuan yang cukup dalam tugasnya. Boner dan Walker (2006), mengatakan bahwa peningkatan pengetahuan yang muncul dari pelatihan formal sama bagusnya dengan yang didapat dari pengalaman khusus. Oleh karena itu pengalaman kerja telah dipandang sebagai suatu faktor penting dalam memprediksi kinerja akuntan publik, sehingga pengalaman dimasukkan sebagai salah satu persyaratan dalam memperoleh ijin menjadi akuntan publik (SK Menkeu No. 43/KMK.017/1997 yang diperbaharui oleh SK MenKeu No.470/KMK.17/1999).

Dalam penelitian ini peneliti memasukan motivasi sebagai variabel moderating dikarenakan motivasi dapat memoderasi hubungan antara diskusi, pengalaman dan kinerja auditor. Hal ini sejalan dengan apa yang dikemukakan oleh Cathleen et.al (2006) dalam penelitiannya menemukan bahwa diskusi yang berhubungan dengan proses pemeriksaan telah meningkatkan motivasi di pihak yang direviu untuk lebih meningkatkan kinerja yang dilakukan, khususnya bagi staf auditor yang pengalamannya kurang. Hal ini dapat terjadi dikarenakan dalam proses umpan balik ataupun menerima umpan balik membutuhkan sejumlah waktu dan pengalaman tertentu. Penelitian ini memodifikasi dan didasari oleh penelitian-penelitian yang dilkukan oleh Miller. et.al. (1999) tentang dampak diskusi verbal dan motivasi serta interaksinya terhadap kinerja staff dimana penelitian ini menganalisa indikator diskusi verbal terhadap motivasi auditor, dimana pengalaman kerja berpengaruh terhadap motivasi demikian pula indikator diskusi verbal berpengaruh terhadap kinerja auditor yang satu sama lain indikator tersebut saling mendukung.

Peneliti tertarik dengan penelitian yang dilakukan oleh Miller at.al ini untuk di aplikasikan pada Kantor BPK RI Perwakilan Sulawesi Utara dengan alasan karena BPK perwakilan Sulawesi Utara memiliki daerah pemeriksaan yang cukup luas yaitu di diseluruh daerah Provinsi Sulawesi Utara yang terdiri dari 15 kabupaten/kota, memiliki staf auditor dan auditor senior yang cukup banyak serta berkompeten dalam bidangnya. Selain itu peneliti juga ingin mengetahui tentang konsistensi dari proses pemeriksaan tentang diskusi verbal dalam review kertas kerja yang dilakukan supervisor dan staf auditor dalam meningkatkan motivasi sehingga berpengaruh terhadap 
peningkatan kinerja auditor. Berdasarkan uraian diatas mendorong penulis untuk mengembangkan penelitian tentang "Pengaruh Diskusi Verbal dalam Review Kertas Kerja Audit, Pengalaman dan Motivasi terhadap Kinerja auditor pada Badan Pemeriksa Keuangan RI perwakilan Sulawesi Utara".

\subsection{Rumusan Masalah}

Rumusan masalah dari penelitian ini adalah :

1. Apakah diskusi verbal atas review kertas kerja audit berpengaruh terhadap kinerja auditor?

2. Apakah pengalaman kerja berpengaruh pada kinerja auditor?

3. Apakah motivasi berpengaruh terhadap kinerja auditor ?

4. Apakah diskusi verbal atas review kertas kerja, pengalaman kerja dan motivasi secara simultan berpengaruh terhadap kinerja?

\subsection{Tujuan Penelitian}

Tujuan dari penelitian ini adalah :

1. Untuk mengetahui apakah diskusi verbal atas review kertas kerja audit berpengaruh terhadap kinerja staf auditor.

2. Untuk mengetahui apakah pengalaman kerja berpengaruh pada kinerja staf auditor.

3. Untuk mengetahui apakah motivasi berpengaruh terhadap kinerja staf auditor.

4. Untuk mengetahui apakah diskusi verbal atas review kertas kerja, pengalaman kerja dan motivasi secara simultan berpengaruh terhadap kinerja

\subsection{Landasan Teoritis}

\section{LANDASAN TEORITIS}

\subsubsection{Audit}

Ada beberapa pengertian audit yang diberikan oleh beberapa ahli di bidang akuntansi, antara lain:

Menurut Arens dan Loebbecke (1995) "Auditing is the accumulation and evaluation of evidence about information to determine and report on the degree of correspondence between the information and established criteria. Auditing should be done by a competent independent person".

Menurut Mulyadi (2002) "Suatu proses sistematik untuk memperoleh dan mengevaluasi bukti secara obyektif mengenai pernyataan-pernyataan tentang kegiatan dan kejadian ekonomi, dengan tujuan untuk menetapkan tingkat kesesuaian antara pernyataan-pernyataan tersebut dengan kriteria yang telah ditetapkan, serta penyampaian haisl-hasilnya kepada pemakai yang berkepentingan".

\subsubsection{Kertas Kerja}

Dalam menjalankan pemerikasaanyan (general audit) Kantor Akuntan public harus berpedoman kepada Standar Profesi Akuntan Publik. Semua prosedur audit yang dilakukan dan temuan-temuan audit harus didokumentasikan ke dalam kertas kerja pemeriksaan. Sesuai dengan Standar Auditing yang ditetapkan Ikatan Akuntansi Indonesia SA seksi 339 Kertas Kerja paragraph 03, definisi kertas kerja adalah catatan-catatan yang diselenggarakan oleh auditor mengenai prosedur audit yang ditempuhnya, pengujian yang dilakukannya, informasi yang diperolehnya, dan simpulan yang dibuatnya sehubungan dengan auditnya. Kertas kerja mencajup seluruh informasi yang dipandang perlu oleh auditor dalam melaksanakan pemeriksaan yang memadai dan mendukung laporan audit, hal ini meliputi bukti-bukti yang dikumpulkan untuk membuktikan bahwa pemeriksaan telah dilakukan, metode dan kesimpulan telah diberikan. Sehingga kertas kerja ini nantinya merupakan dasar bagi auditor untuk mengambil kesimpulan mengenai kewajaran laporan keuangan yang diperiksanya. Kertas kerja dapat saja bervariasi tergantung pada keadaan lapangan yang dihadapi auditor, oleh karena itu pembuatan kertas kerja harus dibuat lengkap, teliti, ringkas, jelas dan rapi. 


\section{a. Tujuan Pemeriksaan Kertas Kerja}

Tujuan menyeluruh atas kertas kerja audit adalah membantu auditor memberikan keyakinan memadai bahwa audit yang layak telah dilakukan sesuai dengan standar audit yang layak telah dilakukan sesuai dengan standar auditing yang telah ditetapkan IAI (Arens \& Loebbecke 2006). Lebih spesifik Mulyadi (2008) menyebutkan tujuan dari pembuatan kertas kerja pemeriksaan adalah sebagai berikut :

a. Mendukung pendapat auditor atas laporan keuangan auditan dan juga merupakan bukti bahwa auditor telah melakukan audit yang memadai.

b. Menguatkan simpulan-simpulan auditor dan kompetisi auditnya jika kemudian hari ada pihakpihak yang memerlukan penjelasan mengenai simpulan atau pertimbangan yang telah dibuat oleh auditor dalam auditnya.

c. Mengkoordinasi dan mengorganisasi semua tahap audit untuk menghasilkan berbagai macam bukti yang membentuk kertas kerja.

d. Dalam audit yang berulang atas klien yang sama dalam periode akuntansi yang berlainan, kertas kerja dapat digunakan sebagai dasar penyusunan audit program dan perencanaan audit tahun-tahun yang akan datang.

Oleh karena itu pembuatan dan penyimpanan kertas kerja merupakan pekerjaan yang penting dalam audit, sehingga untuk dapat menghasilkan kertas kerja yang benar-benar bermanfaat, kertas kerja harus dibuat secara lengkap, teliti, ringkas, jelas dan rapih.

\section{b. Review atas Kertas Kerja}

Menurut Arens dan Loebbecke dalam terjemahan Jusuf (2006) Review atas kertas kerja adalah suatu review atas kertas kerja audit yang diselesaikan oleh staf audit lain untuk mkemastikan kualitas dan untuk menetralisir keterpihakan.

Riview atas kertas kerja dalam suatu kantor akuntan public dilakukan pada berbagai tingkatan. Pada tahap pertama review dilakukan oleh pengawas langsung (supervisor) dari sipembuat kertas kerja, misalnya auditor senior atau manajer. Riview ini dilakukan apabila pekerjaannya atas suatu bagian audit tertentu telah selesai dikerjakan. Riview terutama ditekankan pada pekerjaan apa yang dilakukan, bukti yang diperoleh, dan kesim pulan yang dicapai oleh pembuat kertas kerja (Jusuf 2006)

\subsubsection{Konsep Diskusi}

Menurut Sunaryo (2007) diskusi adalah bertukar pikiran atau membahas suatu masalah dengan mengemukakan dasar-dasar alasannya atau membahas suatu masalah dengan mengemukakan dasar-dasar alasannya atau membahas suatu masalah untuk memecahkannya. Dengan adanya diskusi, peserta diskusi diharapkan mampu bertukar pikiran dengan aktif dalam usaha membahas suatu masalah dan memperoleh pemecahannya.

Diskusi merupakan bagian komunikasi. Komunikasi merupakan suatu ilmu yang termasuk dalam ilmu-ilmu social dan terapan. Ilmu komunikasi diklasifikasikan kedalam : intrapersonal communication, interpersonal communication, group communication, mass communication, intercultural communication dan sebagainya (Effendiy, (2008). Berdasarkan definisi tersebut, diskusi digolongkan kedalam interpersonal communication (tatap muka secara langsung). Dikatakan komunikasi tatapmuka karena ketika komunikasi sedang berlangsung, komunikator dan komunikan saling berhadapan dan saling melihat. Komunikator dapat mengkaji dari si komunikan secara langsung. Begitu juga dengan pelaksanaan komunikasi tatap muka untuk hal periviewan kertas kerja audit dilakukan oleh atasan pada setiap penugasan audit. Dengan demikian bawahan akan bertemu dengan atasan.

Catatan tentang review audit yang ditulis merupakan informasi yang berorientasi pada tugas auditor dan penting untuk didiskusikan kepada atasan sehingga memberikan dampak yang positif terhadap staff auditor terutama didalam peningkatan kerja auditor tetapi akan berdampak negative terhadap staff. Anggota staff yang tidak berpengalaman biasanya kurang terbiasa dengan 
anggota tim audit dari anggota staf yang berpengalaman dan untuk itulah membutuhkan untuk pemersatu seperti diskusi yang bersifat verbal tersebut.

\subsubsection{Motivasi}

Tingkat motivasi antara individu yang satu dengan yang lain beraneka ragam maupun didalam diri seseorang idividu dalam waktu yang berlainan. Dari hasil konsep motivasi tersebut, ada baiknya jika kita melihat lebih lanjut tentang teori-teori motivasi. Salah satu teori motivasi yang paling banyak disebut adalah teori hirarki kebutuhan yang dikemukakan oleh ahli phisikologi Abraham Maslow.

Maslow memandang kebutuhan manusia dalam bentuk suatu hirarki, meningkat dari yang terendah ke yang tertinggi. Kebutuhan manusia yang dikemukakan Maslow menurut urutan pentingnya yaitu :

1. Kebutuhan fisik (Phisiological Needs)

Kebutuhan fisik yaitu kebutuhan untuk mempertahankan hidup. Yang termasuk dalam kebutuhan ini adalah kebutuhan makan, minum, tempat tinggal dan sebagainya.

2. Kebutuhan keamanan atau keselamatan (Safety or Security Needs)

Kebutuhan tingkat kedua menurut maslow adalah kebutuhan untuk terlepas dari bahaya fisik atau ketakutan akan kehilangan pekerjaan, harta atau tempat tinggal

3. Kebutuhan akan afiliasi atau pencritaan (Affiliation or Acceptance Needs)

Karena manusia adalah mahluk social maka ia membutuhkan kawan, butuh untuk diterima oleh orang lain dilingkungan ia hidup dan bekerja serta kebutuhan untuk dihormati oleh orang lain

4. Kebutuhan akan penghargaan (Esteem or Status Needs)

Sekali manusia telah memenuhi kebutuhannya untuk berkawan ia cenderung ingin dihargai, baik oleh dirinya sendiri atau oleh orang lain. Jenis kebutuhan ini menimbulkan kepuasan seperti kekuasaan, prestise, status dan kepercayaan diri.

5. Kebutuhan akan aktualisasi diri (Self Actulization Needs)

Kebutuhan jenjang terakhir menurut Maslow adalah merupakan realisasi lengkap potensi seseorang secara penuh. Pemenuhan kebutuhan uktualisasi berbeda dengan kebutuhan lain dalam dua hal yaitu pertama, kebutuhan aktualisasi diri tidak dapat dipenuhi dari luar, tetapi merupakan usaha individu itu sendiri. Kedua, aktualisasi diri berhubungan dengan pertumbuhan seseorang individu. Kebutuhan ini berlangsung terus-menerus sejalan dengan meningkatnya jenjang karir seorang individu.

\subsubsection{Pengalaman}

Pengalaman kerja telah dipandang sebagai suatu faktor yang penting dalam memprediksi kinerja akuntan public sehingga pengalaman dimasukan sebagai salah satu persyaratan dalam memperoleh ijin menjadi akuntan publik (SK.Men Keu No.43/KMK.017/1997). Stephen (2006) yang mendefinisikan senioritas sebagai masa kerja seseorang pada pekerjaan tertentu, jika demikian maka masa kerja juga dapat diekspresikan sebagai pengalaman kerja. Pengalaman merupakan salah satu elemen penting dalam tugas audit di samping pengetahuan yang harus dimiliki seorang auditor. Dan tidak mengherankan apabila cara memandang dan menanggapi informasi yang diperoleh selama melakukan pemeriksaan antara auditor berpengalaman dengan yang kurang berpengalamanakan berbeda, demikian halnya dalam memberikan kesimpulan audit terhadap obyek yang diperiksa.

Auditor dalam melakukan pekerjaannya menghadapi berbagai ragam permasalahan menyangkut kompleksitas obyek yang diperiksa. Berbagai hal yang ditemukan dalam pemeriksaaan tertentu belum tentu akan ditemui masalah yang sama di lain kesempatan. Pengalaman bagi auditor memegang peran yang sangat penting untuk keberhasilan penugasan pemeriksaaan.

Ton et.al (1999) dalam Suwandi, (1999) mengemukakan bahwa pengetahuan, kemampuan memecahkan masalah dan kompleksitas yang diproleh melalui pengalaman ternyata berpengaruh terhadap kinerja auditor. Suwandi (1999) dalam penelitiannya juga menunjukkan hasil bahwa auditor BPKP yang berpengalaman ternyata mempunyai tingkat profesionalisme yang tinggi, dan 
artinya pengalaman merupakan salah satu faktor penting untuk meningkatkan kinerja internal auditor pemerintah (BPKP).

\subsubsection{Kinerja Auditor}

\section{a. Pengertian Kinerja}

Kinerja merupakan tindakan-tindakan atau pelaksanaan-pelaksanaan tugas yang dapat diukur (Seymour, 2006). As'ad (2006) memberikan batasan bahwa kinerja sebagai kesuksesan seseorang dalam melaksanakan pekerjaan. Sedangkan penulis lain, Byars dan Rue (2008) mendefinisikan kinerja merupakan derajat penyelesaian tugas yang menyertai pekerjaan seseorang. Kinerja adalah yang merefleksikan seberapa baik seseorang individu memenuhi permintaan pekerjaan. Berdasarkan definisi-definisi di atas, menunjukan bahwa kinerja merupakan hasil yang bersifat kuantitatif dan kualitatif.

Byars dan Rue (2008) mengungkapan bahwa kinerja diukur dengan instrument yang dikembangkan dalam studi yang tergabung dalam ukuran kinerja secara umum, kemudian diterjemahkan kedalam penilaian perilaku secara mendasar meliputi :
a. Kualitas kerja
b. Kuantitas kerja
c. Pengetahuan tentang pekerjaan
d. Pendapat atau pernyataan yang disampaikan
e. Keputusan yang diambil
f. Perencanaan kerja
g. Deskripsi pekerjaan

\subsection{Kerangka Konseptual Penelitian}

\section{KERANGKA KONSEPTUAL}

Berdasarkan kerangka teoritis maka Kerangka konseptual yang diteliti oleh Miller at.al (1999) memberikan inspirasi untuk memodifikasi pemikiran tersebut tentang pengaruh diskusi verbal dalam review kertaas kerja audit, pengalaman kerja dan motivasi terhadap kinerja staf auditor. Kemudian kerangka pemikiran tersebut dijelaskan dalam gambar 2.1 seperti dibawah ini.

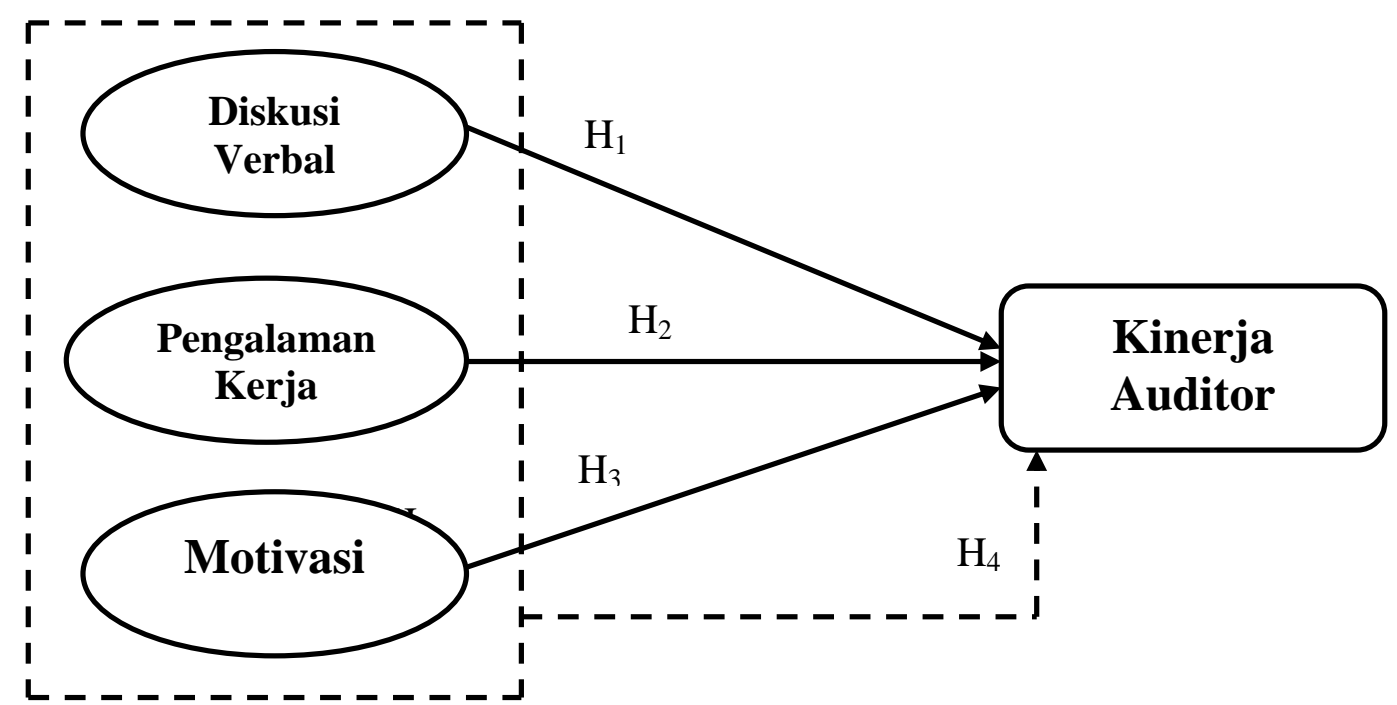

Gambar 3.1 Kerangla Konseptual

\subsection{Hipotesis Penelitian}

Hipotesis adalah penjelasan sementara yang harus diuji kebenarannya mengenai masalah yang sedang dipelajari, dimana suatu hipotesis selalu dirumuskan dalam bentuk pernyataan yang menghubungkan dua variabel atau lebih. 


\section{Pengaruh diskusi verbal dalam review kertas kerja audit terhadap kinerja auditor}

Diskusi juga dapat meningkatkan kinerja secara langsung (Sulivan, 1988). Diskusi menyediakan tambahan informasi tugas secara spesifik yang meningkatkan pemahaman bagaimana tugas-tugas seharusnya dilakukan (Ilgen et al. 1979; Earley, 1988; Sulvian, 1988). Dalam penelitian Early (1988) bahwa partisipan menyatakan bahwa feedback yang lebih spesifik menyebabkan mereka berpikir lebih mengenai tugas-tugasnya, sehingga tambahan informasi yang disediakan dalam feedback menimbulkan kinerja lebih baik.Akhirnya Goodson et al. (1992), menduga bahwa feedback yang berorientasi pada tugas menyebabkan pemahaman yang jelas mengenai kinerja yang diharapkan dan mendorong pengembangan perencanaan tindakan selanjutnya, sihingga menghasilkan capaian kinerja. Berdasarkan argumen-argumen tersebut, maka dapat dikembangkan hipotesis sebagai berikut :

$\mathrm{H}_{\mathrm{a} 1}$ : Diskusi verbal atas review kertas kerja audit berpengaruh terhadap kinerja staf auditor

\section{Pengaruh pengalaman kerja terhadap kinerja auditor}

Beberapa penelitian yang dilakukan seperty Hillery dan Wexley (1974), Goodson et al (1992) telah menguji feedback pada berbagai tingkat pengalaman yang berbeda pula agar peningkatan kinerja dapat dicapai. Secara umum penelitian ini menemukan bahwa dalam pelatihan individu-individu yang kurang berpengalaman akan memperoleh manfaat lebih besar dari tugas yang telah berorientasi, top-down dan feedback "mengapa" disbanding individu-individu yang berpengalaman.

Goodson et al. (1992) menemukan bahwa para menejer pada level bawah (kurang berpengalaman) merupakan penguat hubungan antara isi feedback dan outcomes disbanding pada menejer yang berpengalaman. Feedbak mengurangi ketidakpastian outcomes pada manajer kurang berpengalaman (lower manager), oleh karena itu feedback telah mendorong motivasi. Pada manajer berpengalaman tidak memiliki banyak ketidakpastian outcome karena pengalamannya itu. Penelitian Goodson et al. (1992) mengindikasikan bahwa diskusi mengenai kinerja dalam review lebih efektif pada manajer yang kurang berpengalaman tetapi tidak membantu manajer yang berpengalaman. Berdasarkan argumen-argumen tersebut, maka dapat dikembangkan hipotesis sebagai berikut :

$\mathrm{H}_{\mathrm{a} 2}$ : Pengalaman Kerja berpengaruh terhadap kinerja staff auditor

\section{Pengaruh motivasi terhadap kinerja auditor}

Klein (1989) menggambarkan motivasi sebagai "proses psykhologi yang disebabkan inisiasi (initiation), arahan (direction), maksud (intensity), dan presistensi (persistence) dari perilaku". Motivasi adalah salah satu metode mengurangi ketidakpastian kerja, oleh karena itu motivasi memperjelas sasaran kerja karyawan (Locke, 1997). Motivational Language Theory (MLT) mendukung pernyataan inni (Sullivan, 1988), dimana MLT menambahkan bahwa bahasa mendorong motivasi untuk mencapai kinerja karena memperjelan tugas-tugas tertentu misalnya tugas audit dan mengurangi ketidakpastian tugas (Early, 1988; Sullivan, 1988). Berdasarkan argumen-argumen tersebut, maka dapat dikembangkan hipotesis sebagai berikut :

$\mathrm{H}_{\mathrm{a} 3}$ : Motivasi berpengaruh terhadap kinerja staff auditor.

Berdasarkan landasan teori kerangka konseptual dan hasil-hasil penelitian terdahulu dalam penelitian ini maka hipotesis yang dikembangkan dalam penelitian ini adalah sebagai berikut :

$\mathrm{H}_{01}$ : Diskusi verbal atas review kertas kerja audit tidak berpengaruh terhadap kinerja staf auditor.

$\mathrm{H}_{\mathrm{a} 1}$ : Diskusi verbal atas review kertas kerja audit berpengaruh terhadap kinerja staf auditor.

$\mathrm{H}_{02}$ : Pengalaman Kerja tidak berpengaruh terhadap kinerja staff auditor

$\mathrm{H}_{\mathrm{a} 2}$ : Pengalaman Kerja berpengaruh terhadap kinerja staff auditor

$\mathrm{H}_{03}$ : Motivasi tidak berpengaruh terhadap kinerja staff auditor

$\mathrm{H}_{\mathrm{a} 3}$ : Motivasi berpengaruh terhadap kinerja staff auditor

$\mathrm{H}_{04}$ : Diskusi verbal atas review kertas kerja audit, pengalaman kerja dan motivasi tidak berpengaruh terhadap kinerja staf auditor 
$\mathrm{H}_{\mathrm{a} 4}$ : Diskusi verbal atas review kertas kerja audit, pengalaman kerja dan motivasi berpengaruh terhadap kinerja staf auditor

\subsection{Model Analisis}

Untuk penelitian ini, dilakukan pengujian dengan model analisis regresi linier berganda. Menurut Sugiyono (2004), analisis regresi linear berganda digunakan oleh peneliti bila peneliti bermaksud meramalkan bagaimana keadaan (naik turunnya) variabel dependen bila dua atau lebih variabel independen sebagai faktor prediktor dimanipulasi (dinaik turunkan nilainya) dengan menggunakan formula sebagai berikut:

$$
\begin{aligned}
& \text { Keterangan : } Y=\text { Kinerja Auditor } \\
& \beta_{1}=\text { koefisien regresi untuk } X_{1} \\
& \beta_{2}=\text { koefisien regresi untuk } X_{2} \\
& \beta_{3}=\text { koefisien regresi untuk } X_{3} \\
& X_{1}=\text { Diskusi Verbal } \\
& X_{2}=\text { Pengalaman Kerja } \\
& X_{3}=\text { Motivasi } \\
& \varepsilon=\text { error sampling }
\end{aligned}
$$

\section{HASIL PENELITIAN DAN PEMBAHASAN}

\subsection{Pengujian Validitas dan Reabilitas}

\section{a) Pengujian Validitas}

Sugiyono dan Wibowo (2004), ketentuan validitas instrument sahih apabila $\mathrm{r}$ hitung lebih besar dari $r$ kritis $(0,244)$. Suyuthi $(2005)$, item pernyataan atau pertanyaan dinyatakan valid jika mempunyai nilai $r$ hitung yang lebih besar dari $r$ standar yaitu 0,244. Sugiyono (2004), bila korelasi

\begin{tabular}{|c|c|c|c|c|}
\hline \multirow{2}{*}{ Variabel } & \multirow{2}{*}{ Indikator } & \multicolumn{3}{|c|}{ Korelasi (r) } \\
\hline & & $\mathbf{R}$ & Sig & Status \\
\hline \multirow{6}{*}{ Diskusi Verbal (X1) } & $\mathrm{X}_{1} 1$ & 0,595 & 0,000 & Valid \\
\hline & $X_{1} 2$ & 0,694 & 0,000 & Valid \\
\hline & $\mathrm{X}_{1} 3$ & 0,516 & 0,000 & Valid \\
\hline & $X_{1} 4$ & 0,668 & 0,000 & Valid \\
\hline & $X_{1} 5$ & 0,727 & 0,000 & Valid \\
\hline & $\mathrm{X}_{1} 6$ & 0,669 & 0,000 & Valid \\
\hline \multirow{4}{*}{ Pengalaman Kerja (X2) } & $\mathrm{X}_{2} 1$ & 0,546 & 0,000 & Valid \\
\hline & $X_{2} 2$ & 0,833 & 0,000 & Valid \\
\hline & $X_{2} 3$ & 0,812 & 0,000 & Valid \\
\hline & $\mathrm{X}_{2} 4$ & 0,790 & 0,000 & Valid \\
\hline \multirow{10}{*}{ Motivasi (X3) } & $\mathrm{X}_{3} 1$ & 0,470 & 0,000 & Valid \\
\hline & $X_{3} 2$ & 0,562 & 0,000 & Valid \\
\hline & $X_{3} 3$ & 0,599 & 0,000 & Valid \\
\hline & $X_{3} 4$ & 0,843 & 0,000 & Valid \\
\hline & $X_{3} 5$ & 0,741 & 0,000 & Valid \\
\hline & $\mathrm{X}_{3} 6$ & 0,796 & 0,000 & Valid \\
\hline & $X_{3} 7$ & 0,831 & 0,000 & Valid \\
\hline & $\mathrm{X}_{3} 8$ & 0,646 & 0,000 & Valid \\
\hline & $\mathrm{X}_{3} 9$ & 0,865 & 0,000 & Valid \\
\hline & $X_{3} 10$ & 0,682 & 0,000 & Valid \\
\hline
\end{tabular}
tiap faktor positif dan besarnya 0,244 ke atas maka faktor tersebut merupakan construct yang kuat. Uji validitas digunakan untuk mengukur sah atau tidaknya suatu indikator yang berbentuk kuisioner. Jadi, validitas menunjukkan seberapa cermat suatu alat tes melakukan fungsi ukurnya atau suatu alat ukur yang dapat mengukur apa yang ingin diukur. Pengujian validitas variabel Diskusi Verbal (X1), Pengalaman Kerja (X2), Motivasi (X3), Kinerja Auditor (Y) dengan menggunakan Software SPSS Version 18.0 sebagai berikut :

Tabel 4.1. Tabel Hasil Validitas 


\begin{tabular}{|l|c|c|c|c|}
\hline \multirow{2}{*}{ Variabel } & \multirow{3}{|c|}{ Korelasi (r) } \\
\hline \multirow{4}{*}{ Indikator } & $\mathbf{R}$ & Sig & Status \\
\cline { 2 - 5 } & & 0,908 & 0,000 & Valid \\
\cline { 2 - 5 } & Y1 & 0,931 & 0,000 & Valid \\
\cline { 2 - 5 } & Y2 & 0,866 & 0,000 & Valid \\
\cline { 2 - 5 } & Y3 & 0,856 & 0,000 & Valid \\
\cline { 2 - 5 } & Y4 & 0,870 & 0,000 & Valid \\
\cline { 2 - 5 } & Y5 & 0,828 & 0,000 & Valid \\
\cline { 2 - 5 } & Y6 & 0,789 & 0,000 & Valid \\
\cline { 2 - 5 } & Y7 & 0,826 & 0,000 & Valid \\
\cline { 2 - 5 } & Y8 & 0,887 & 0,000 & Valid \\
\cline { 2 - 5 } & Y9 & 0,831 & 0,000 & Valid \\
\hline
\end{tabular}

Dari hasil pengujian diatas dapat dilihat bahwa seluruh instrument dalam penelitian ini telah valid.

\section{b) Pengujian Reliabilitas.}

Seperti yang telah dijelaskan sebelumnya dalam Bab III bahwa metode pengujian reliabilitas adalah dengan menggunakan analisis Reliability melalui metode Cronbach Alpha yang diukur berdasarkan skala alpha 0 sampai dengan 1. Ukuran kemantapan alpha dapat diinterpretasi seperti pada Tabel 4.2 berikut.

Tabel 4.2. Tingkat Reliabilitas Berdasarkan Nilai Alpha

\begin{tabular}{|c|c|}
\hline Alpha & Tingkat Reliabilitas \\
\hline $0,00 \mathrm{~s} / \mathrm{d} 0,20$ & Kurang Reliabel \\
$>0,20 \mathrm{~s} / \mathrm{d} 0,40$ & Agak Reliabel \\
$>0,40 \mathrm{~s} / \mathrm{d} 0,60$ & Cukup Reliabel \\
$>0,60 \mathrm{~s} / \mathrm{d} 0,80$ & Reliabel \\
$>0,80 \mathrm{~s} / \mathrm{d} 1,00$ & Sangat Reliabel \\
\hline
\end{tabular}

Sumber : Triton P.B (2006:248)

Setelah data diolah dengan menggunakan bantuan Software SPSS Version 18.0 untuk menguji tingkat reliabilitas, maka output yang dihasilkan dapat dilihat pada Lampiran 3 yang dapat ditunjukkan pada Tabel 4.3 berikut

\section{1) Variabel Diskusi Verbal $\mathbf{X}_{1}$}

Tabel 4.3. Tabel Uji Reabiliti Variabel Diskusi Verbal $X_{1}$

\begin{tabular}{|c|c|c|}
\hline $\begin{array}{c}\text { Cronbach's } \\
\text { Alpha }\end{array}$ & $\begin{array}{c}\text { Cronbach's } \\
\text { Alpha Based on } \\
\text { Standardized } \\
\text { Items }\end{array}$ & N of Items \\
\hline, 682 &, 735 & 6 \\
\hline
\end{tabular}

\section{Sumber : Data Penelitian Telah Diolah, 2016}

Dari pengujian tingkat reliabilitas seperti yang disajikan pada tabel 5.10, maka pada bagian Reliability statistics terdapat cronbach's alpha $=0,682$ dengan $N$ of items atau butir pertanyaan sebanyak 6 pertanyaan. Jadi oleh karena nilai cronbach alpha hasil output $=$ 0,682 terletak diantara 0,60 hingga 0,80 (tabel 5.9) sehingga tingkat reliabilitasnya adalah reliable. 
2) Variabel Pengalaman Kerja $\mathbf{X}_{2}$

Tabel 4.4. Tabel Uji Reabiliti Variabel Pengalaman Kerja $X_{2}$

\begin{tabular}{|r|r|r|}
\hline \multicolumn{1}{|c|}{$\begin{array}{c}\text { Cronbach's } \\
\text { Alpha }\end{array}$} & $\begin{array}{c}\text { Cronbach's } \\
\text { Alpha Based on } \\
\text { Standardized } \\
\text { Items }\end{array}$ & N of Items \\
\hline, 738 &, 736 & 4 \\
\hline
\end{tabular}

Sumber : Data Penelitian Telah Diolah, 2016

Dari pengujian tingkat reliabilitas seperti yang disajikan pada tabel 4.4, maka pada bagian Reliability statistics terdapat cronbach's alpha $=0,738$ dengan $N$ of items atau butir pertanyaan sebanyak 4 pertanyaan. Jadi oleh karena nilai cronbach alpha hasil output = 0,738 terletak diantara 0,60 hingga 0,80 (tabel 5.9) sehingga tingkat reliabilitasnya adalah reliable.

3) Variabel Motivasi $\mathbf{X}_{3}$

Tabel 4.5. Tabel Uji Reabiliti Variabel Motivasi $X_{3}$

\begin{tabular}{|r|r|r|}
\hline $\begin{array}{c}\text { Cronbach's } \\
\text { Alpha }\end{array}$ & $\begin{array}{c}\text { Cronbach's } \\
\text { Alpha Based on } \\
\text { Standardized } \\
\text { Items }\end{array}$ & N of Items \\
\hline, 878 &, 889 & 10 \\
\hline
\end{tabular}

Sumber : Data Penelitian Telah Diolah, 2016

Dari pengujian tingkat reliabilitas seperti yang disajikan pada tabel 4.5 , maka pada bagian Reliability statistics terdapat cronbach's alpha $=0,878$ dengan $N$ of items atau butir pertanyaan sebanyak 10 pertanyaan. Jadi oleh karena nilai cronbach alpha hasil output = 0,738 terletak diantara 0,80 hingga 0,100 sehingga tingkat reliabilitasnya adalah sangat reliable.

\section{4) Variabel Kinerja Auditor Y}

Tabel 4.6. Tabel Uji Reabiliti Variabel Kinerja Auditor Y

\begin{tabular}{|r|r|r|}
\hline $\begin{array}{c}\text { Cronbach's } \\
\text { Alpha }\end{array}$ & $\begin{array}{c}\text { Cronbach's } \\
\text { Alpha Based on } \\
\text { Standardized } \\
\text { Items }\end{array}$ & N of Items \\
\hline, 959 &, 961 & 10 \\
\hline
\end{tabular}

Sumber : Data Penelitian Telah Diolah, 2016

Dari pengujian tingkat reliabilitas seperti yang disajikan pada tabel 4.6, maka pada bagian Reliability statistics terdapat cronbach's alpha $=0,959$ dengan $N$ of items atau butir pertanyaan sebanyak 10 pertanyaan. Jadi oleh karena nilai cronbach alpha hasil output = 0,959 terletak diantara 0,80 hingga 0,100 (tabel 4.6) sehingga tingkat reliabilitasnya adalah sangat reliable.

2. Analisis Regresi Linear Berganda

Tabel 4.7 Coefficients ${ }^{\mathrm{a}}$

\begin{tabular}{|c|c|c|c|c|c|c|}
\hline \multirow{2}{*}{\multicolumn{2}{|c|}{ Model }} & \multicolumn{2}{|c|}{ Unstandardized Coefficients } & \multirow{2}{*}{$\begin{array}{c}\text { Standardized } \\
\text { Coefficients } \\
\text { Beta }\end{array}$} & \multirow[t]{2}{*}{$\mathrm{T}$} & \multirow[t]{2}{*}{ Sig. } \\
\hline & & $B$ & Std. Error & & & \\
\hline \multirow{4}{*}{1} & (Constant) & 71,534 & 9,437 & & 7,581 & ,000 \\
\hline & $\mathrm{X} 1$ & 1,996 & ,345 & .585 & 5,777 & ,000 \\
\hline & $\mathrm{X} 2$ & ,802 & ,357 & 245 & 2,245 & ,028 \\
\hline & X3 & ,931 & ,131 & 297 & 2,995 & ,024 \\
\hline
\end{tabular}

Sumber : Data Penelitian Telah Diolah, 2016

Berdasarkan hasil perhitungan dengan menggunakan bantuan software SPSS version 18.00 seperti pada table 4.7, maka persamaan regresi yang diperoleh adalah sebagai berikut :

$\mathbf{Y}=\alpha+\beta_{1} \mathbf{X}_{1}+\beta_{2} \mathbf{X}_{2}+\beta_{3} \mathbf{X}_{3}+\mathbf{e}$

$Y=71,534+1,996 X 1+0,802 X 2+0,931 X 3$

Dengan interpretasi bahwa : 
Konstanta $\alpha$ sebesar 71,534 memberikan pengertian bahwa jika Diskusi Verbal (X1), Pengalaman (X2), Motivasi (X3) sama dengan nol (0), maka besarnya kinerja auditor BPK 71,534 satuan skor. Nilai $\beta 1$ yang merupakan koefisien regresi dari variabel Diskusi Verbal (X1) sebesar 1,996, ini mempunyai arti bahwa jika Diskusi Verbal meningkat sebesar 1 satuan skor, maka akan mengalami peningkatan Kinerja Auditor BPK sebesar 1,996 satuan skor dari kondisi sebelumnya, dengan asumsi variabel lainnya tetap. Nilai $\beta 2$ yang merupakan koefisien regresi dari variabel Pengalaman Kerja (X2) sebesar 0,802, ini mempunyai arti bahwa jika Pengalaman Kerja meningkat sebesar 1 satuan skor, maka akan mengalami peningkatan Kinerja Auditor BPK sebesar 0,802 satuan skor dari kondisi sebelumnya, dengan asumsi variabel lainnya tetap. Dan nilai $\beta 3$ yang merupakan koefisien regresi dari variabel Motivasi (X3) sebesar 0,931, ini mempunyai arti bahwa jika Motivasi meningkat sebesar 1 satuan skor, maka akan mengalami peningkatan Kinerja Auditor BPK sebesar 0,931 satuan skor dari kondisi sebelumnya, dengan asumsi variabel lainnya tetap.

\section{Uji F dan Uji t}

\section{1) Hasil Uji F}

Tabel 4.8. Tabel Hasil Uji F

\begin{tabular}{|rl|r|r|r|r|r|}
\hline Model & & Sum of Squares & Df & Mean Square & F & Sig. \\
\hline \multirow{4}{*}{1} & Regression & 919,517 & 3 & 306,506 & 12,876 &, $000^{\text {b }}$ \\
& Residual & 1452,021 & 61 & 23,804 & & \\
& Total & 2371,538 & 64 & & & \\
\hline
\end{tabular}

Sumber : Data Penelitian Telah Diolah, 2016

Dari tabel di atas, dapat diketahui hasil $\mathrm{F}_{\text {hitung }}=12,876$ dan $\mathrm{F}_{\text {tabel }}$ dengan tingkat keyakinan sebesar 95\% dimana df 1 (4-1) dan df 2 (65-4-1) adalah sebesar 2,76 dengan hasil signifikan 0,000. Jadi dapat dilihat bahwa $\mathrm{F}_{\text {hitung }}>\mathrm{F}_{\text {tabel }}$ maka dapat disimpulkan bahwa Ho ditolak dan Ha diterima. Selanjutnya dapat dilihat pada signifikan $0,000<0,05$, maka dapat dinyatakan bahwa Secara simultan, variabel Diskusi Verbal, Pengalaman Kerja dan Motivasi berpengaruh secara signifikan terhadap Kinerja Auditor.

2) Hasil Uji t

Tabel 4.9. Tabel Hasil Uji t

Coefficients $^{\mathrm{a}}$

\begin{tabular}{|c|c|c|c|c|c|c|}
\hline \multirow{2}{*}{\multicolumn{2}{|c|}{ Model }} & \multicolumn{2}{|c|}{ Unstandardized Coefficients } & \multirow{2}{*}{$\begin{array}{c}\text { Standardized } \\
\text { Coefficients } \\
\text { Beta }\end{array}$} & \multirow[t]{2}{*}{$\mathrm{T}$} & \multirow[t]{2}{*}{ Sig. } \\
\hline & & $B$ & Std. Error & & & \\
\hline \multirow{4}{*}{1} & (Constant) & 71,534 & 9,437 & & 7,581 & ,000 \\
\hline & $\mathrm{X} 1$ & 1,996 & 345 & .585 & 5,777 & ,000 \\
\hline & $X 2$ & 802 & 357, & 245 & 2,245 & ,028 \\
\hline & X3 & ,931 & , 131 & ,297 & 2,995 & ,024 \\
\hline
\end{tabular}

Sumber : Data Penelitian Telah Diolah, 2016

Hasil $t_{\text {hitung }}$ untuk variabel Diskusi Verbal $\left(\mathrm{X}_{1}\right)=5.777$ dan signifikan 0,000 serta $t_{\text {tabel }}=$ 2,000. Dari hasil tersebut dapat dilihat bahwa $t_{\text {hitung }}>t_{\text {tabel }}$ dapat dinyatakan bahwa Ho ditolak dan Ha diterima dan tingkat signifikan $0,000<0,05$ Dengan demikian Diskusi Verbal berpengaruh signifikan terhadap Kinerja Auditor.

Hasil $t_{\text {hitung }}$ untuk variabel Pengalaman $\left(X_{2}\right)=2,245$ dan signifikan 0.028 serta $t_{\text {tabel }}=2,000$. Dari hasil tersebut dapat dilihat bahwa $t_{\text {hitung }}>t_{\text {tabel }}$ dapat dinyatakan bahwa Ho ditolak dan Ha diterima dan tingkat signifikan 0,028 $<0,05$ Dengan demikian Pengalaman Kerja berpengaruh signifikan terhadap Kinerja Auditor.

Hasil $t_{\text {hitung }}$ untuk variabel Motivasi $\left(X_{3}\right)=2.995$ dan signifikan 0,024 serta $t_{\text {tabel }}=2,000$. Dari hasil tersebut dapat dilihat bahwa $t_{\text {hitung }}>t_{\text {tabel }}$ dapat dinyatakan bahwa Ho ditolak dan Ha diterima dan tingkat signifikan 0,028 $<0,05$ Dengan demikian motivasi berpengaruh signifikan terhadap Kinerja Auditor. 


\subsection{Kesimpulan}

\section{KESIMPULAN DAN SARAN}

berikut:

Berdasarkan hasil pembahasan sebelumnya, maka dapat ditarik kesimpulan sebagai

1. Dari uji $\mathrm{F}$ dapat diketahui hasil $\mathrm{F}_{\text {hitung }}=12,876$ dan $\mathrm{F}_{\text {tabel }}$ dengan tingkat keyakinan sebesar 95\% dimana df 1 (4-1) dan df 2 (65-4-1) adalah sebesar 2,76 dengan hasil signifikan 0,000. Jadi dapat dilihat bahwa $\mathrm{F}_{\text {hitung }}>\mathrm{F}_{\text {tabel }}$ maka dapat disimpulkan bahwa Ho ditolak dan $\mathrm{Ha}$ diterima. Selanjutnya dapat dilihat pada signifikan $0,000<0,05$, maka dapat dinyatakan bahwa Secara simultan, variabel Diskusi Verbal, Pengalaman Kerja dan Motivasi berpengaruh secara signifikan terhadap Kinerja Auditor.

2. Dari uji $t$ dapat diketahui hasil $t_{\text {hitung }}$ untuk variabel Diskusi Verbal $\left(\mathrm{X}_{1}\right)=5.777$ dan signifikan 0,000 serta $t_{\text {tabel }}=2,000$. Dari hasil tersebut dapat dilihat bahwa $t_{\text {hitung }}>t_{\text {tabel }}$ dapat dinyatakan bahwa $\mathrm{H}_{\mathrm{o}}$ ditolak dan Ha diterima dan tingkat signifikan $0,000<0,05$ Dengan demikian Diskusi Verbal berpengaruh signifikan terhadap Kinerja Auditor.

3. Dari uji $t$ dapat diketahui hasil $t_{\text {hitung }}$ untuk variabel Pengalaman $\left(\mathrm{X}_{2}\right)=2,245$ dan signifikan 0.028 serta $t_{\text {tabel }}=2,000$. Dari hasil tersebut dapat dilihat bahwa $t_{\text {hitung }}>t_{\text {tabel }}$ dapat dinyatakan bahwa Ho ditolak dan Ha diterima dan tingkat signifikan 0,028 <0,05 Dengan demikian Pengalaman Kerja berpengaruh signifikan terhadap Kinerja Auditor.

4. Dari uji $t$ dapat diketahui hasil $t_{\text {hitung }}$ untuk variabel Motivasi $\left(X_{3}\right)=2.995$ dan signifikan 0,024 serta $t_{\text {tabel }}=2,000$. Dari hasil tersebut dapat dilihat bahwa $t_{\text {hitung }}>t_{\text {tabel }}$ dapat dinyatakan bahwa Ho ditolak dan Ha diterima dan tingkat signifikan 0,028 < 0,05 Dengan demikian motivasi berpengaruh signifikan terhadap Kinerja Auditor.

\subsection{Saran} antara lain:

Berdasarkan hasil pembahasan dalam penelitian ini, adapun saran yang diajukan penulis,

1. Ada baiknya jika Kantor BPK RI Perwakilan Sulawesi Utara, perlu memperhatikan, meningkatkan dan mengintensifkan diskusi verbal dalam riview kertas kerja audit, pengalaman kerja dan motivasi yang ada dalam Kantor BPK tersebut, karena terbukti memiliki hubungan yang erat dan memiliki pengaruh yang signifikan terhadap kinerja auditor yang ada dalam Kantor BPK tersebut.

2. Peneliti selanjutnya diharapkan dapat menggali faktor-faktor lain yang dapat memberikan pengaruh yang cukup besar terhadap kinerja yang ada dalam suatu perusahaan atau organisasi, tentunya dengan mempertimbangkan segala keterbatasan yang ada dalam penelitian ini.

\section{DAFTAR PUSTAKA}

Abdul Halim 2008, Auditing I (Dasar-dasar Audit Laporan Keuangan), AMP YPKN, Yogyakarta.

Aiken, L. S, and S. G West 1991, Multiplw Regression: Testing and Interpreting Interactions Sage Publications, Newbury Park, CA

Arens, A.A., J.K. Loebbecke. 2000. Auditing: An Integrated Approach. EightEdition. New Jersey: Prentice Hall International Inc.

As'ad Muchamad, 2008. Psikologi Industri, Liberty, Yogyakarta

Bamber, E. M. dan L. H. Bylinski, 1986. The Effect of the Planing Memorandum, Tims Pressure and Individual Auditor Charakteristik on Audit Manager's Riview Time Judgements. Contemporary Accounting Research 4:127-143

Byars, L.L, Rue L.W, 2008, Management : Theory and Application, Ricard D. Irwin Inc, Homewood IL 
Dessler, G, 2008, Manajemen Personalia, terjemahan, Erlangga, Jakarta.

Early, P. C. 1988. Computer-General Performance feedback in the Magazine-Subscription Industry.

Organizational Behavior and Human Decicion Process : 50-64

Effendy, Onong Uchjana, 1999, Ilmu Komunikasi, Teori dan Praktek, PT Remaja Rosdakarya, Bandung

Flipo, EB, 1984, Personal Manajemen, Sixth Edition, Mc Graw-Hill Book co. Singapore

Gibson, James 1, Jhon M Ivancevuch dan James H Donnely Jr, 2009, Organisasi dan Manajemen Perilaku, Struktur, Proses, Edisi 4, terjemahan, Penerbit Erlangga, Jakata.

Goodson.J.R.G.W McGee dan A.Seers. 1992. Giving Approppriate Performance Feedback to Managers: An Emperical Test of Conten and Outcome, The Journal of Bussines Comunication: $329-342$

Hammer. W.C dan D.W Organ, 1978 Organizational Behavior, an Applied Phychology Apprach (Bussines Publication)

Harsey, Paul and Kenneth H, Blancard, 2006, Management of Organizational Behavior Utilizing Human Resouces, $4^{\text {th }}$ edition, Prentice-Hall, Inc, terjemahan, Penerbit Erlangga, Jakarta.

Heidjarachman Ranupandojo, 2008, Organizational Behavior and Applied Psychology Approach (Bussines Publication)

Hillery, J.M dan K.N.Wexley. 1974 Participation Effect in Appraisal Interviews Conducted in Training Situation, Journal of Applied Psychology 168-171

Ilyas Meifida, dan Yudhi Herliansyah, 2009. Diskusi Verbal Dalam Review Kertas Kerja, Motivasi, Interaksi antara Diskusi dan Pengalaman Pengaruhnya Terhadap Kinerja Auditor. Jurnal Ilmiah Satya Negara Indonesia Vol. 2, No. 1, Juni 2009 : 32-49

Ikatan Akuntan Indonesia, 2001. Standar Profesional Akunhtan Publik : per 1 Januari 2001, Salemba Empat, Jakarta.

Ismail, Z, and K.T. Trotman. 1995. The Impact of the Review Process in Hypothesis Generation Task, Acounting organization and Society $12: 345-357$

Karmer, M. W 1993. Communication and Uncertaitly Reduction During Job Transfer Leaving and Joining Process. Communication Monographs (juni) : 178-179

Kuncorohadi, Drs, 2007. Pokok-pokok Perilaku Organisasi, Semarang Undip

Libby, R dan J. Luft. 1993. Determiant of Judgement Performance in Accounting Setting, Ability, Knowledge, Motivation and Environment. Organization and Society 18:425-450

Luthan, F. 2005, Organizational Behavior, Sevend Edition, Mc Graw-Hill.

Mardiasmo. 2008. Akuntansi Sektor Publik Edisi 2. Penerbit Andi. Yogyakarta

Miller, C.C, L.M. Burke and W.H.H. Glick (1999), Cognitive Diversity Among Upper Echelon Executive: Implication for Strategic Decision Process, Strategic Management Journal, 19, pp.39-58

Mulyadi. 2008. Auditing, Edisi 6, Salemba Empat, Jakarta.

Mulyadi. 2008. Pemeriksaan Akuntan. Yogyakarta: Badan Penerbit STIE YKPN

Ngalim Purwanto, 2008. Psikologi Pendidikan, Bandung. Penerbit PT. Remaja Rosdya Raya

O'Reilly et al.1998 O'Reilly, R. C., Munakata, Y., \& McClelland, J. L. (1998). Computational Cognitive Neuroscience: Understanding the Mind by Simulating the Brain. MIT Press, Cambridge, MA

Poerwadarminto, 2005. Kamus Besar Indonesia, Edisi II, Jakarta, Balai Pusaka.

Robbins, S.P., T.A. Judge. 2008. Perilaku Organisasi, edisi 12. Jakarta: Salemba Empat.

Seymour, J. Madison, AID University Linkages for Agriculturl Development, Journal of Higher Education, Vol 62, No:3 p:288-316

Sularso, Sri. 1998. Pengaruh Pengalaman Akuntan Pemeriksa terhadap Pengetahuan dan Penggunaan Intuisinya Mengenai Kekeliruan, Tesis.

Sunarsip, 2008, Coorporat Governance Audit : Paradigma Baru Profesi Akuntansi dalam Mewujudkan Good Coorporate Gvernance, Media Akuntansi, No.17/Th. VII.pp. II-VII

Sunaryo.1989. Stategi Belajar Mengajar dalam llmu Pengetahuan Sosial. Jakarta:Depdikbud 
Suwandi dan Nur Indriantoro, 1999. Pengujian Model Turnover Pasewark dan Strawer : Studi Empiris pada Lingkungan Akuntansi Publik, Jurnal Riset Akuntansi Indonesia, Vol 2, No 2 , pp 173-192

Stoner, James. A.F., and Carles Wankel, 2005, Management, Third Edition, Prentice-Hall International, Inc, Engelewood Cllifs, New Jersey.

Trotman, Ken T, and P.W Yetton, 1985. The Effect of The Review Process on Audits Judgment. Journal of Accounting hResearch, Vol 23, No. 2,pp. 257-266

Wahyudi, Yusni, 2003. Analisis Pengaruh Diskusi Verbal Dalam Riview Kertas Kerja dan Motivasi Serta Interaksinya Terhadap Kinerja Auditor Di Jawa Tengah. Tesis

www.bpk.go.id

www.manado.bpk.go.id 